\title{
Effect of cefepime on hematological, immunological and oxidant/antioxidant parameters in rats experimentally infected
} with E. coli ATCC 25922

\author{
Huda S. Elbaz ${ }^{1}$, Mohamed F. Hamed ${ }^{2}$ Fatma M. Abdelhamid ${ }^{1 *}$, Osama A. Abdalla ${ }^{3}$ \\ ${ }^{1}$ Department of Clinical Pathology, Faculty of Veterinary Medicine, Mansoura University, Mansoura,35516, Egypt \\ ${ }^{2}$ Department of Pathology, Faculty of Veterinary Medicine, Mansoura University, Mansoura 35516, Egypt \\ ${ }^{3}$ Deparment of Clinical Pathology , Faculty of Veterinary Medicine, Suez Canal University, Ismailia, Egypt
}

\section{ARTICLE HISTORY}

Received: 18.01 .2020

Revised: 10.03 .2020

Accepted: 14.03 .2020

Address correspondence to Fatma. Abdelhamid; Tel: +201019108001; Fax: +2050/2200696; E-mail: E-mail: : fatmamostafa980@yahoo.com

\begin{abstract}
Objective: To evaluate the effect of cefepime on hematological changes, immunological disorders and hepatic oxidative damage in rats experimentally infected with E.coli ATCC 25922.

Design: Randomized controlled experimental study.

Animals: Thirty-two adult male albino rats weighting150-200 g.

Procedures: Rats used for this study were randomly assigned into 4 equal groups: the control one, E.coli infected group $\left(1 \times 10^{8} \mathrm{CFU} / \mathrm{I} / \mathrm{P} /\right.$ once), the cefepime treated group (45 $\mathrm{mg} / \mathrm{kg}$ bw/l/M/day) for 5 days and the E.coli infected group that treated with cefepime $24 \mathrm{~h}$ after bacterial inoculation as previously described. Hematological and immunological parameters, liver function biomarkers and hepatic oxidative stress and antioxidant markers were determined.

Results: Our result revealed that E.coli infection induced a significant elevation in the erythrocytes count, hemoglobin concentration, PCV\% and total leukocytic count (TLC) $(P<0.05)$. In the same respect, liver function biomarkers, serum glucose, total cholesterol, and triglyceride levels as well hepatic malondialdehyde (MDA), nitric oxide (NO), TNF- $\alpha$, IL-10, and lysozyme activity were significantly increased compared to the control rats $(P<0.05)$. In contrast, hepatic reduced glutathione $(G S H)$, superoxide dismutase (SOD) and catalase (CAT) were decreased significantly $(P<0.05)$. Cefepime treatment in E.coli + CFPM group reduced the elevated eythrogram, TLC and liver function biomarkers. Cefepime also ameliorated the oxidative damage and inflammatory response induced by E.coli infection.

Conclusion and clinical relevance: Cefepime is safe when administered in a fixed-dose and possess antioxidant that contributes to improve efficacy against adverse effect induced by E.coli ATCC 25922 infection.
\end{abstract}

Keywords: Cefepime, E.coli ATCC 25922, Hepatic oxidative damage, Immunological

parameters, Rats.

\section{INTRODUCTION}

Gram-negative bacteria have often been implicated in the pathogenesis of severe infections, which are important causes of death in critical cases [1]. Escherichia coli (E. coli) is one of the main species of bacteria that normal inhabitants lower intestines of warm-blooded animals, including birds and mammals [2]. There are many studies recorded physiological changes and host immune reactions occur during infection with E.coli such as inflammatory response initiation, and an increase in cellular permeability [3]. Many Escherichia coli isolates are sensitive to several antibiotics used for the treatment of their different complications, although other strains are becoming resistant to them, especially antibiotics that are broadly used [4].

Cefepime (CFPM) is a fourth-generation of semisynthetic broad-spectrum cephalosporin one of a class of beta-lactam antibiotics that have a bactericidal action against most Gram-positive Streptococcus pneumonia, Gramnegative including E.coli and anaerobic bacteria but not against methicillin-resistant Staphylococcus aureusorenterococcus [5].

CFPM has been first approved by the FDA in 1997 to be used as first-line empiric therapy for serious infections, including lower respiratory tract infections, acquired and nosocomial pneumonia, complicated and uncomplicated urinary tract infections, skin and skin structure infections, bacterial otitis media, sepsis and bacterial septicemia[6, 7].Cefepime, like to other $\beta$-lactams, is a bactericidal agent that prevents bacterial cell wall biosynthesis by covalent attachment to penicillin-binding proteins and hinders the final transpeptidation phase of the peptidoglycan layer of bacterial cell walls synthesis[8]. Cefepime has a property to increase the antioxidant capacity of the body and provide 
effective scavenging of free radicals that give rise to lipid peroxidation, impair cell membranes and induce oxidative damage of DNA[9]. Therefore, our study was designed to investigate the efficacy of treatment with cefepime on hematological disturbance, hepatic damage, immunological changes induced by Escherichia coli infection in rats.

\section{MATERIALS AND METHODS}

\subsection{The Pharmaceutical Drug}

Cefepime hydrochloride (Maxipime ${ }^{\bullet}$-Vial) was purchased from Bristol-Meyers Squibb, USA

\subsection{Bacterial strain}

E.coli serotype ATCC 25922 was purchased from the Animal Health Research Institute, Cairo, Egypt.

\subsection{Animal and experimental design}

Thirty-two adult healthy male albino rats, weighing 150$200 \mathrm{~g}$, were purchased from Zagazig laboratory animal unit and housed under controlled conditions $\left(25 \pm 1^{\circ} \mathrm{C}\right)$. Standard rodent pellet diet and water were provided ad libitum. The rats were handled in accordance with animal welfare and the protocol approved by the Animal Ethical Committee of the Faculty of Veterinary Medicine, Mansoura University, Egypt. After two weeks of acclimatization, rats were divided into the following experimental groups; control group received distilled water orally, E.coli infected group (infected with E.coli ATCC 25922, $1 \times 10^{8}$ CFU / I/P/once) according to Sánchez et al. [10], cefepime treated group (CFPM) (intramuscularly injected with cefepime at a dose of $45 \mathrm{mg} / \mathrm{kg}$ bw/ day for 5 days) according to Elsayed et al. [11] and the E.coli infected group treated with cefepime $24 \mathrm{~h}$ after infection (E.coli +CFPM) as was previously described.

\subsection{Blood and tissue samples collection}

At the $7^{\text {th }}$ day post-treatment, two blood samples were withdrawn from the medial canthus of the eye, the first sample in Eppendorf tubes with EDTA for hematological examination and the second samples were collected in clean test tubes for serum separation. Serum was separated and stored in Eppendorf tubes at $-20^{\circ} \mathrm{C}$ to be used for biochemical and immunological analysis. After that, animals were cervically dislocated then one gram of liver tissues was immediately dissected from each rat then was perfused with chilled $0.85 \% \mathrm{NaCl}$ solution and homogenized at $9 \mathrm{ml}$ iced phosphate buffer saline (PH 7.5). The homogenate was cold centrifuged for 15 minutes at $825 \mathrm{Xg}$ to get the supernatant that collected carefully and used directly or stored into Eppendorf tubes at $-80^{\circ} \mathrm{C}$ for further use [12].Specimens from the liver were fixed in $10 \%$ neutral buffered formaldehyde for histopathological studies.

\subsection{Hematological parameters}

Whole blood was used for the total erythrocytic (RBCs) and leukocytic counts (TLC). Hemoglobin concentration ( $\mathrm{Hb}$ cont.) and packed cell volume (PCV) were determined then red blood cell indices were evaluated [13].

\subsection{Serum biochemical analysis}

The serum alanine aminotransferase (ALT) and aspartate aminotransferase (AST) were measured by using diagnostic kits obtained from (Colorimetric Randox, UK). Meanwhile, alkaline phosphatase (ALP) was estimated with commercial diagnostic kits (Teco diagnostics, USA). The bilirubin was estimated by Diamond kits (Egypt), while total protein and albumin were detected using Stanbio Laboratory (USA) kits.Glucose, cholesterol, and triglycerides were measured by using ready-made kits provided by Spinract (Spain). All the parameters were spectrophotometrically detected (5010 photometer, BM Co., Berlin, Germany) according to the enclosed pamphlets.

2.7. Measurement of hepatic oxidative stress and antioxidant markers

The hepatic malondialdehyde (MDA), superoxide dismutase (SOD), catalase (CAT), and reduced glutathione (GSH) were detected spectrophotometrically by the enzymatic colorimetric method using Bio-diagnostic kits (Egypt), referring to the manufacturer's protocols.

\subsection{Measurement of some serum immunological parameters}

Serum lysozyme was determined by the turbidimetric assay[14]. The lysozyme substrate was $0.75 \mathrm{mg}$ of Micrococcus Lysodeikticus Lyophilized Cells (Sigma-Aldrich) which was suspended in $1 \mathrm{ml}$ of PBS, $\mathrm{pH} 5.8$. In the round bottom, a microtitre plate $25 \mu$ of serum was added to each well with $175 \mu$ l of substrate solution at $25^{\circ} \mathrm{C}$. The reduction in absorbance at $450 \mathrm{~nm}$ was read after zero and twenty minutes using microtitre plate ELISA reader. The unite of lysozyme in serum in $\mu \mathrm{g} / \mathrm{ml}$ was obtained from the lysozyme curve made by Lyophilized hen egg-white lysozyme (SigmaAldrich).

Two hundred microliter of serum or Hank's Balanced Salt Solution as control was added to duplicate wells of 96 round bottom well microtiter plate and incubated for $2.5 \mathrm{~h}$ at room temperature with $50 \mu \mathrm{L}$ of suspension live a $24 \mathrm{~h}$ culture of E.coli $3 \times 10^{8} \mathrm{CFU}$. To each well, $25 \mu \mathrm{L}$ diphenyltetrazolium bromide solution (MTT; $2 \mathrm{mg} / \mathrm{ml}$ ) (Sigma) was added and incubated for thirty minutes at room temperature to allow the formation of formazan. Then the supernatant was discarded and the precipitate was dissolved in two hundred microliters of dimethyl sulfoxide (DMSO). The absorbance was read at $560 \mathrm{~mm}$ with microtitre plate ELISA readers and reported as absorbance units [15].

\section{Estimation of serum nitric oxide}

Nitric oxide (NO) was determined by a colorimetric assay spectrophotometrically (BM Co., Germany, 5010) by Biodiagnostic kits [16].

Measurement of serum tumor necrosis factor- $\alpha$ (TNF- $\alpha$ ) and interleukin-10 s (IL-10)

TNF- $\alpha$ and IL-10 were estimated using Rat ELISA kit provided by Quantikine Company, using an automatic microplate ELISA reader (Human Diagnostic, Co., Germany) 
according to the manufacturer's protocols. The values were expressed as $\mathrm{pg} / \mathrm{ml}[17,18]$.

\subsection{Histopathological studies}

Specimens from the hepatic tissue were fixed in $10 \%$ neutral buffered formalin then were embedded in paraffin. Section of 5-micron thickness was prepared and stained by hematoxylin \& eosin (H \&E) and examined microscopically [19].

\subsection{Statistical Analysis}

Results were expressed as the mean \pm standard error and were analyzed were using one-way analysis of variance (ANOVA) followed by Duncan's multiple range test, $\mathrm{P}<0.05$ was considered significant. All statistical analyses were performed using a statistical software program SPSS for Windows, version 23(IBM, Armonk, NY, USA) and Graphs were performed using GraphPad Prism version 5 (GraphPad Software Inc., La Jolla, CA, USA).

\section{RESULTS}

\subsection{Hematological results}

The RBC count, $\mathrm{Hb}$ concentration, PCV, and TLC were significantly increased in E.coli infected rats, compared to the control group. While $\mathrm{MCV}, \mathrm{MCH}$, and $\mathrm{MCHC}$ were insignificantly changed in between all groups $(P<0.05)$. The treatment with cefepime in the E.coli + CFPM group reduced the RBCs, Hb, PCV and TLC to their normal values. No noticeable differences were observed in the hematological picture in the CFPM group as compared to the control $(\mathrm{P}<$ 0.05) (Table 1).

\subsection{Serum biochemical results}

The ALT, AST and ALP serum activities as well the serum levels of total, direct, and indirect bilirubin were significantly raised in the E.coli infected rats in comparison with the control group $(\mathrm{P}<0.05)$. On the other hand, all of the previous parameters were dramatically reduced upon the treatment with cefepime in the E.coli + CFPM group compared to theE.coli infected non-treated one $(P<0.05)$ (Table 2). No significant differences were recorded in the total protein, albumin, globulin, and $A / G$ ratio in between all groups $(P<$ 0.05) (Table 2).

Total cholesterol and triglyceride levels were significantly elevated in E.coli infected group comparing with the control meanwhile they were significantly reduced in the E.coli + CFPM compared to the E.coli infected group. The same direction was adopted by the glucose level in the serum (Table2).

\subsection{Hepatic oxidative stress and antioxidant markers}

As displayed in the Figure.1, experimentally E.coli infection in rats induced hepatic oxidative damage reflected by a significant elevation in the MDA level while SOD\& CAT activities and GSH levels were significantly reduced compared with the control rats. These alterations were improved upon the treatment with cefepime in the E.coli +CFPM group. It was also noted that cefepime treatment in the CFPM group insignificantly altered the hepatic oxidative stress and antioxidant markers $(P<0.05)$.

Table 1.Hematological parameters in rat experimentally infected with E. coli ATCC 25922 and treated with cefepime.

\begin{tabular}{|c|c|c|c|c|}
\hline \multirow[b]{2}{*}{ Prameter } & \multicolumn{2}{|l|}{ Treatment } & \multirow[b]{2}{*}{ CFPM } & \multirow[b]{2}{*}{ E.colitCFPN } \\
\hline & Control & E.coli & & \\
\hline RBCs $06 / \mu \mathrm{L}$ & $5.29 \pm 0.27^{b}$ & $6.15 \pm 0.26^{a}$ & $5.14 \pm 0.21^{b}$ & $5.34 \pm 0.06^{b}$ \\
\hline $\mathrm{Hb}$ g/dl & $13.58+0.55^{b}$ & $14.79+0.35^{a}$ & $13.01+0.18^{b}$ & $13.23 \pm 0.30^{b}$ \\
\hline PCV \% & $46.20 \pm 0.37^{b}$ & $50.40 \pm 0.87^{a}$ & $46.60 \pm 0.50^{b}$ & $46.40 \pm 1.02^{b}$ \\
\hline MCV fl & $89.44+4.86^{a}$ & $82.48+3.73^{a}$ & $91.03+3.08^{a}$ & $86.80 \pm 2.08^{a}$ \\
\hline $\mathrm{MCH}$ pg & $21.30 \pm 2.13^{a}$ & $17.77 \pm 0.9^{a}$ & $21.3 \pm 1.12^{a}$ & $17.70 \pm 0.74^{a}$ \\
\hline $\mathrm{MCHC} \%$ & $29.05 \pm 1.26^{a}$ & $29.86 \pm 0.60^{a}$ & $27.96 \pm 0.66^{a}$ & $28.54 \pm 0.54^{a}$ \\
\hline $\operatorname{TLC} 10^{3} / \mu \mathrm{L}$ & $13.48 \pm 0.58^{b}$ & $18.37 \pm 1.35^{a}$ & $13.58 \pm 0.87^{b}$ & $13.54 \pm 0.36^{b}$ \\
\hline
\end{tabular}

E.coli (infected with E.coli), CFPM (cefepime treatment $45 \mathrm{mg} / \mathrm{kg}$ bw/day), E.coli +CFPM (E.coli infected and treated with cefepime)

Data are expressed as Mean \pm standard error of the mean $(n=8)$. The different letters show significant difference between groups $(P<0.05)$.

$R B C s$, Red blood cell count; $H b$, Hemoglobin; PCV, Packed cell Volume; $M C V$, mean corpuscular volume; $M C H$, mean corpuscular hemoglobin; $M C H C$, mean corpuscular hemoglobin concentration;TLC, Total leukocytic count

\subsection{Serum immunological results}

As presented in Figure 2, the serum lysozyme activity and NO level were significantly increased in the E.coli infected group $(P<0.05)$. Following the treatment with cefepime in the E.coli +CFPM, the above-mentioned parameters significantly decreased compared with the E.coli non treated group.

The serum bactericidal activity was insignificantly altered between all tested groups. Meanwhile, the serum level TNF$\alpha$ and IL-10 were significantly elevated in the E.coli infected group with respect to control one $(P<0.05)$. But, their levels were significantly decreased in the E.coli +CFPM treated group compared to the E.coli non treated one $(\mathrm{P}<0.05)$.

\subsection{Histopathological results}

E.coli infected group showed marked hepatocyte necrosis and intense lymphocytic infiltration in the hepatic lobules. Meanwhile, the E.coli +CFPM group showed mild lymphocytic infiltration in the hepatic tissue with normal hepatocytes. The hepatic sections of the CFPM group showed normal hepatocytes with normal histological architecture similar to the control rats (Figure 3 ). 
Table 2. Serum biochemical parameters in rat experimentally infected with E. coli ATCC 25922 and treated with cefepime.

\begin{tabular}{|c|c|c|c|c|}
\hline \multirow[b]{2}{*}{ Prameter } & \multicolumn{4}{|l|}{ Treatment } \\
\hline & Control & E.coli & CFPM & E.coli + CFPM \\
\hline ALT U/L & $25.08 \pm 0.72^{c}$ & $38.54 \pm 0.91^{a}$ & $25.94 \pm 1.15^{c}$ & $29.00 \pm 1.10^{\mathrm{b}}$ \\
\hline AST U/L & $\pm 0.54^{`} 60.19$ & $73.81 \pm 1.38^{a}$ & $60.92 \pm 0.43^{c}$ & $63.45 \pm 0.29^{b}$ \\
\hline ALP U/L & $524.26 \pm 8.69^{c}$ & $720.26 \pm 11.01^{a}$ & $530.60 \pm 9.74^{c}$ & $596.72 \pm 9.44^{b}$ \\
\hline Total bilirubin (mg/dl) & $0.48 \pm 0.00^{c}$ & $0.58 \pm 0.00^{a}$ & $0.50 \pm 0.01^{c}$ & $0.53 \pm 0.00^{b}$ \\
\hline Direct bilirubin ( $\mathrm{mg} / \mathrm{dl}$ ) & $0.30 \pm 0.01^{b}$ & $0.41 \pm 0.02^{\mathrm{a}}$ & $0.32 \pm 0.00^{b}$ & $0.38 \pm 0.02^{\mathrm{a}}$ \\
\hline Indirect bilirubin (mg/dl) & $0.18 \pm 0.01^{\mathrm{a}}$ & $0.16 \pm 0.02^{\mathrm{a}}$ & $0.18 \pm 0.01^{a}$ & $0.15 \pm 0.02^{\mathrm{a}}$ \\
\hline Total Protein g/dl & $7.28 \pm 0.36^{a}$ & $6.44 \pm 0.19^{a}$ & $6.40 \pm 0.45^{a}$ & $6.42 \pm 0.28^{a}$ \\
\hline Albumin g/dl & $3.01 \pm 0.08^{a}$ & $3.04 \pm 0.11^{\mathrm{a}}$ & $3.06 \pm 0.04^{a}$ & $2.95 \pm 0.19^{a}$ \\
\hline Globulin g/dl & $4.27 \pm 0.37^{a}$ & $3.39 \pm 0.12^{\mathrm{a}}$ & $3.33 \pm 0.46^{a}$ & $3.47 \pm 0.31^{\mathrm{a}}$ \\
\hline A/G ratio & $0.73 \pm 0.07^{a}$ & $0.90 \pm 0.03^{a}$ & $0.98 \pm 0.11^{\mathrm{a}}$ & $0.88 \pm 0.12^{\mathrm{a}}$ \\
\hline Glucose mg/dl & $73.40 \pm 2.31^{\mathrm{b}}$ & $89.23 \pm 3.43^{a}$ & $76.30 \pm 1.85^{b}$ & $75.05 \pm 2.47^{b}$ \\
\hline Cholesterol mg/dl & $60.31 \pm 186^{b}$ & $68.80 \pm 0.86^{a}$ & $60.80 \pm 1.82^{\mathrm{b}}$ & $65.20 \pm 0.58^{a}$ \\
\hline Triglyceride mg/dl & $138.60 \pm 3.50^{b}$ & $179.20 \pm 5.64^{\mathrm{a}}$ & $132.20 \pm 3.08^{b}$ & $139.20 \pm 1.59^{b}$ \\
\hline
\end{tabular}

E.coli (infected with E.coli), CFPM (cefepime treatment $45 \mathrm{mg} / \mathrm{kg}$ bw/day)), E.coli +CFPM (E.coli infected and treated with cefepime) Data are expressed as Mean \pm standard error of the mean $(n=8)$. The different letters show significant difference between groups $(\mathrm{P}<0.05)$.

$A L T$ : Alanine aminotransferase, AST:Aspartate aminotransferase, ALP:Alkaline Phosphatase, $A / G$ ratio: Albumin/Globulin ratio
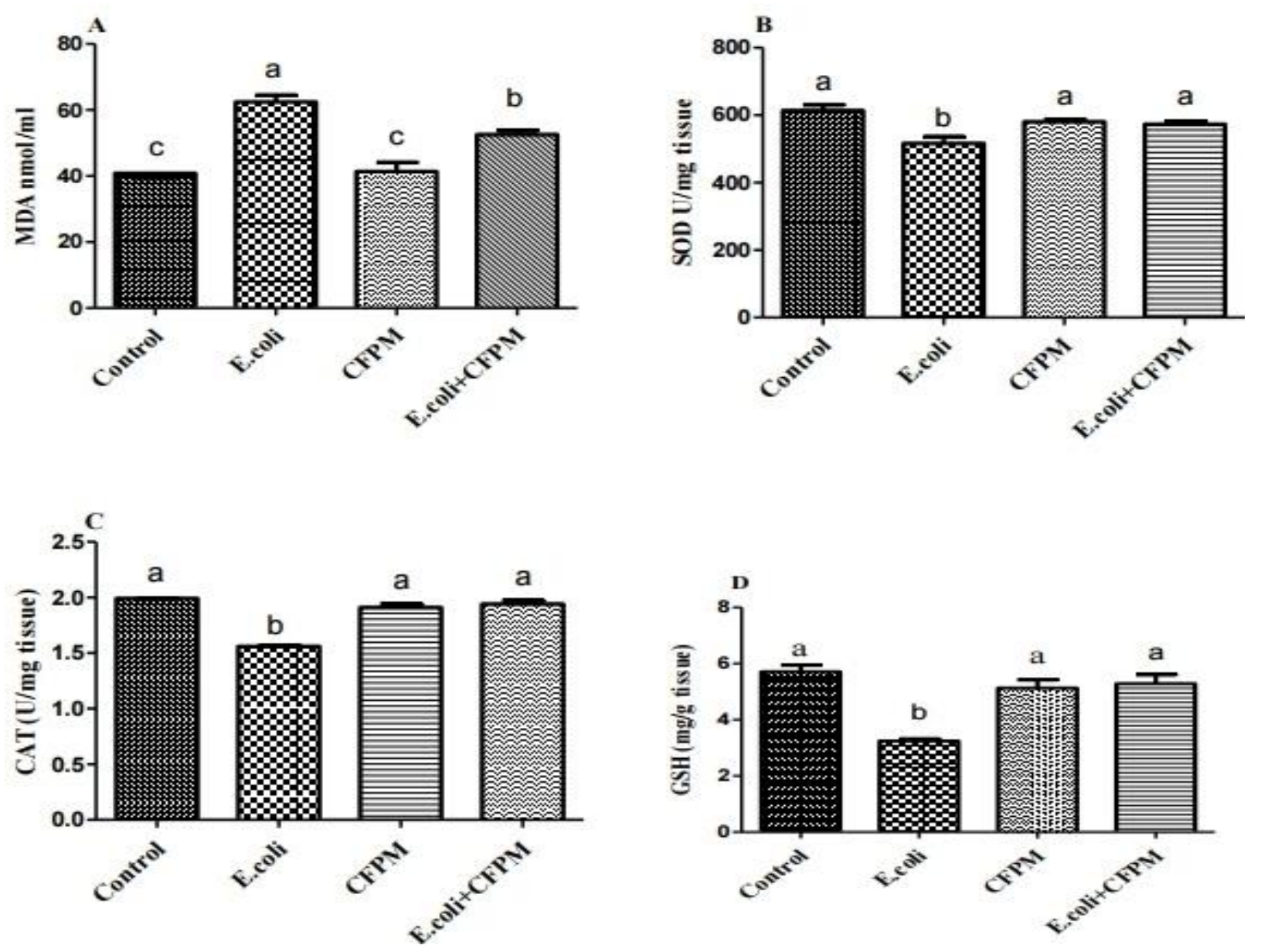

Figure 1. The hepatic (A) MDA level (B) SOD activity (C)CAT activity (D) GSH level in rat experimentally infected with E. coli ATCC 25922 and treated with cefepime 

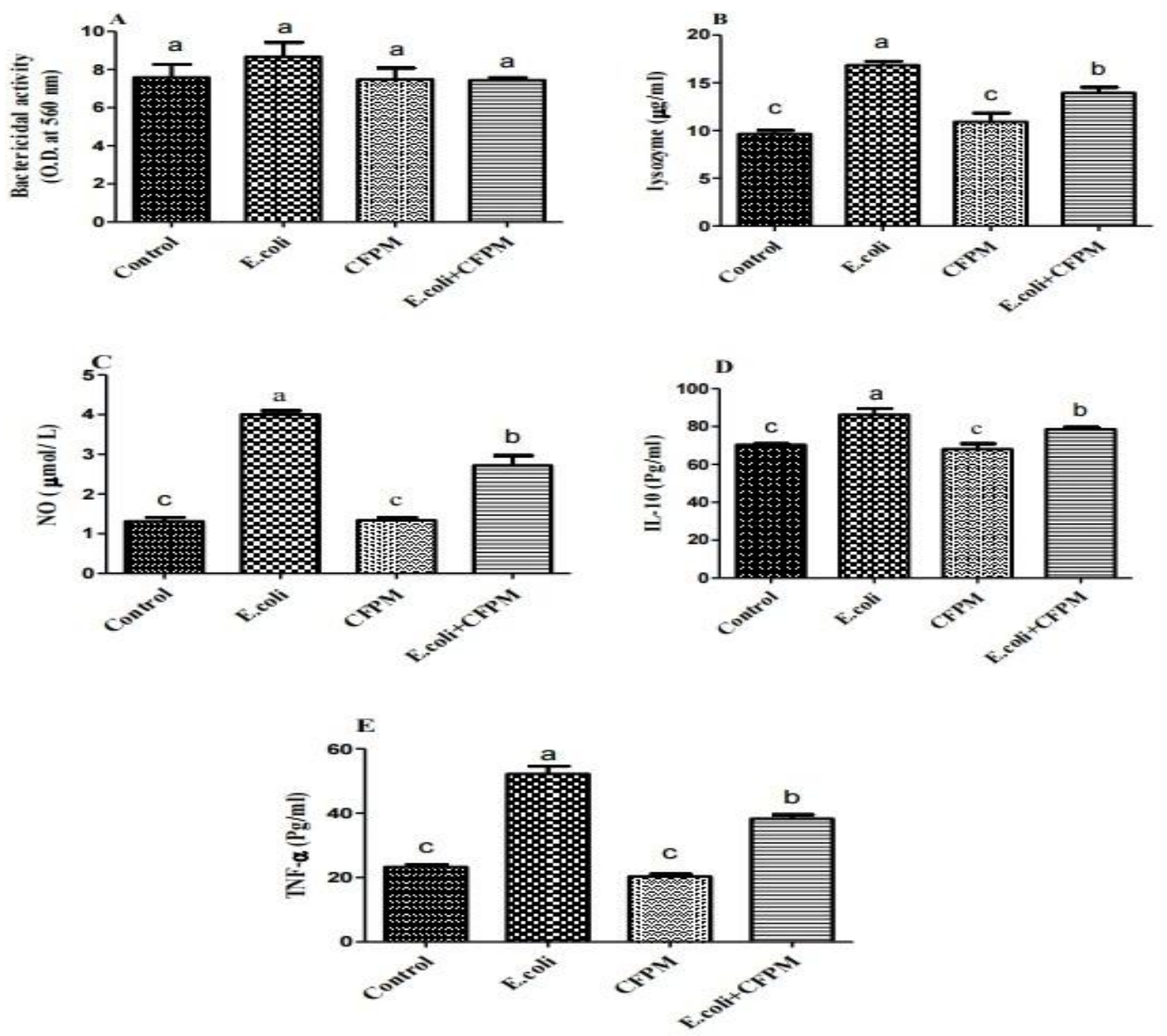

Figure 2. The serum (A) Bactericidal activity, (B) Lysozyme activity, (C) Nitric oxid level (D) IL-10 level (E) TNF- $\alpha$ level in rat experimentally infected with E. coli . ATCC 25922 and treated with cefepime
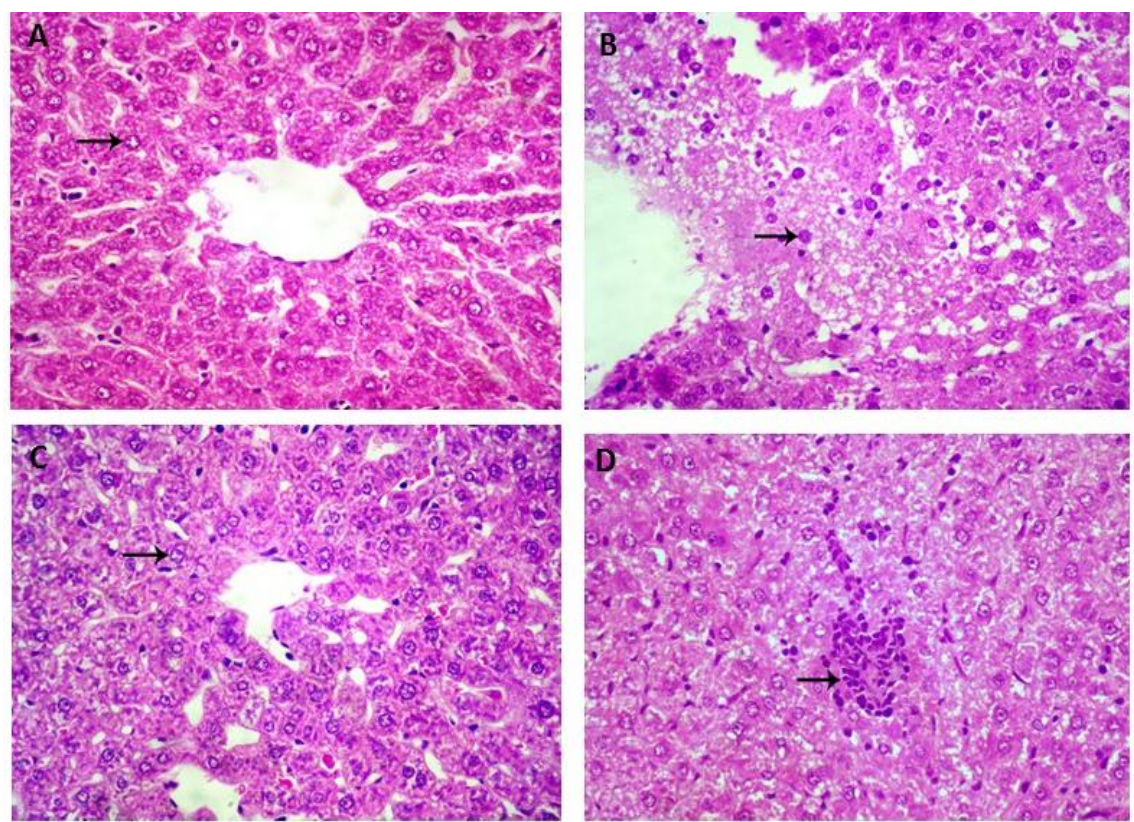

Figure 3. Hepatic micrograph (H\&E, $\times 400$ ) of the A) Control group shows normal hepatocytes (arrow) with normal hepatic architecture. B) The micrograph of E.coli rat shows necrosis of hepatic tissue and dysplastic alteration of hepatocytes (arrow). C) CFPM group shows normal hepatocytes (arrow) with normal hepatic architecture. D)The micrograph of E.coli +CFPM group shows histiocytic infiltrate in hepatic tissue (arrow). 


\section{DISCUSSION}

E.coli has been shown to worldwide induce outbreaks of diarrhea, hemorrhagic colitis [20], pyelonephritis and its recurrent infections can be associated with fibrosis [21]. Cefepime is a newer semisynthetic, broad-spectrum fourthgeneration oxyimino-cephalosporin agent being used progressively for treatment of infections caused by resistant gram-negative bacteria[22] as it has long elimination half-life, contribute in its potent protective properties [23].

The erythrogram result of this work revealed, that the E.coli infection led to a significant increase in RBCs count, $\mathrm{Hb}$ concentration and PCVcompared to control. This may be an indication of the occurrence of relative polycythemia, as a result of acute enteritis induced by E.coli colonization in the small intestine, resulting in severe diarrhea and extensive dehydration [24]. In the existing study, the treatment of rats with cefepime alone has an insignificant effect on the arthrogram result compared to control and these findings agreed with Abou-Samra [25]. On the other hand, the E.coli infected group treated with CFPM revealed improvement in the erythrogram results, which may be a good indication for its bactericidal activity, and this is agreed with Arhoumah et al. [26].

In our study, leukocytosis was detected in E.coli infected rats which gives a signal that infection has been established and there is the production of more white blood cells by the animal to fight E. coli[27]. Concerning the treatment with cefepime, there was an improvement in TLC induced by E.coli infection in comparison with E.coli non-treated rats. This is supported by Arhoumah et al. [26]who reported that the feverish rats infected with lipopolysaccharide from E.coli and treated with cefepime revealed a significant decrease in the TLC.

The biochemical analysis of liver function can provide some valuable data on the condition of the liver. The elevation in the serum activity of ALT and AST, in particular, is associated with hepatocellular degeneration and necrosis[28]. The hyperbilirubinemia can occur after bacteremia and endotoxemia is the reason for septic jaundice[29, 30]. The results of the present study indicated that E.coli infection resulted in hepatotoxicity detected by remarkable elevation of serum liver function biomarkers. This in accordance with Unger et al. [31] who reported that E.coli bacteremia caused a redistribution of hepatic microvascular blood flow within the liver lobule leads to perfusion of certain microvascular segments and decrease perfusion of others, which produced an elevation in liver enzymes. Moreover, E.coli infection also induced obstructive jaundice in the animal [32]. Our data can be confirmed by the histopathological results, which revealed necrosis of hepatic tissue and dysplastic alteration of hepatocytes.

Our data showed some improvement upon CFPM treatment in the E.coli + CFPM treated group that detected by the significant reduction in the elevated liver function biomarkers induced by E.coli infection nearly to the control levels. This may be due to the bactericidal effect of cefepime against infection with gram-negative bacteria [5] Additionally, cefepime documented to have free radical scavenging property which may contribute to reduce hepatotoxicity [9] as a consequence of a direct drug scavenging capacity towards $\mathrm{HOCl}$ [33]. The same results reported by Oter et al. [34] in Wistar rats injected by $E$. coli $\left(2.1 \times 10^{9} \mathrm{CFU}\right.$ by I/P) and treated with CFPM.

In our work, no statically changed was detected in the serum TP, albumin and globulin levels as well as $A / G$ ratio in all investigated groups. These results agree with Risha [35]who observed that serum level of TP, albumin and globulin levels insignificantly changed in Guinea pig I/P injection with E.coli $\left(1-2 \times 10^{8}\right)$ compared with the control group. Additionally, Abou-Samra [25] found no noticeable alterations in TP and albumin in rats intramuscular treated with CFPM at different doses (50 and $100 \mathrm{mg} / \mathrm{kg}$ bw for 10 consecutive days) compared to the control group.

Bacterial endotoxin can have a bad impact on the cellular functions of the liver, which plays an important role in glucose homeostasis [34]. In our study, E.coli infected rats showed a significant increase in blood glucose levels all over the experiment compared to the control group, which may be attributed to severe hepatic dysfunction and the elevated ratio between corticosteroids and insulin-induced by E.coli that affect hepatic glucose metabolism and altered glucose homeostasis [36, 37].

In our work CFPM treatment in the CFPM group insignificantly changed the serum glucose level all over the experiment compared to control. Our results were in agreement with what was previously stated by Elsayed et al. [11]. Our data further suggest that treatment with CFPM in the E.coli +CFPM group improved the elevated serum level of glucose-induced by E.coli in rats. This may be due to the bactericidal effect of cefepime, which caused changes in the enzymatic activities in the metabolism of hepatic glucose and glucose homeostasis[38].

Our data indicated that total cholesterol and triglycerides were significantly increased in E.coli infected group. This is referred to metabolic dysregulation as E.coliinfection accelerated free radicals release that enhances cellular cholesterol accumulation by increasing cholesterol biosynthesis and its esterification and decreasing its utilization by inhibition of cholesteryl ester hydrolysis and reducing cholesterol efflux, consequently caused hyperlipidemic effect[39]. In the existing study, cholesterol and triglyceride levels were significantly reduced upon administration of CFPM in the E.coli +CFPM group, which may be referred to the bactericidal effect of the antibiotics, which caused amelioration in lipid metabolism. These data agree with Ozbudak et al.[40]who mentioned that I/M injection of cefepime significantly reduced the elevated total serum cholesterol caused by Pseudomonas aeruginosa strain ATCC 1942.

Malondialdehyde (MDA) is the most important component among reactive aldehydes originating from lipid peroxidation. Consequently, it is commonly considered as an 
index for oxidative stress severity [41]. In this work, E.coli induced an elevation in the hepatic MDA level that was related to excessive free radicals production, mediated oxidative stress and lipid peroxidation as well as cellular toxicity [42]. In contrast, our data showed that hepatic activities of SOD and CAT enzymes, as well as hepatic GSH, were significantly reduced in E.coli infected group. This could have occurred a consequence of interference with hepatic intracellular oxidant/antioxidant balance and accumulation of reactive oxygen species (ROS) upon E.coli infection [43]

The treatment with CFPM alone insignificantly affected the hepatic MDA level, SOD, CAT activities and GSH level, although treatment with cefepime in E.coli +CFPM group induced a significant reduction in the hepatic MDA, whilst hepatic SOD, CAT, and GSH were significantly increased PT. According to Soejima et al.[44] cephalosporins as cefepime are thioether had free radical scavenging potential and effective in preventing the free radical-mediated oxidation of sulfhydryl group resulted in reduce hepatic oxidative damage.

Lysozyme is an enzyme lytic the cell walls of certain bacteria, it is a protein in nature existing in the body fluids, cells and tissue of many living organisms where it appears to have a digestive and defense function[45]. The serum bactericidal activity is an important host defense mechanism, which plays a role in preventing the initiation of $E$. coli infection [46]. In our study, E.coli resulted in significantly increased the serum lysozyme activity, as the result of increased lysozyme gene transcription $[47,48]$ or increased lysozyme release during infection from the lysosomal compartment because of phagocytosis-induced degranulation[49].

Nitric oxide is a short-lived, highly reactive free radical, synthesized from L-arginine by the enzyme nitric oxide synthase[50]. Herein, the serum NO level was remarkably elevated in E.coli infected group. This could be explained by E.coli infection increases the expression of nuclear factor kappa B (NF- $\kappa \mathrm{B})$ which led to over-expression of inflammatory mediators such as cytokines and inducible NO synthase (iNOs)which is responsible for the excessive formation of NO [51]. Furthermore, the increase of TNF- $\alpha$ led to increasing NO which cause tissue damage by inducing iNOs [52]. the treatment by CFPM in E.coli +CFPM group associated with a significant reduction in the NO level that may be correlated with the ability of CFPM to inhibit TNF- $\alpha$ induced by E.coli endotoxin consequently led to decrease NO[53].

Macrophages in response to many Gram-positive and Gram-negative bacteria produce TNF- $\alpha$ which is important for fighting bacterial infection. Also, IL-10 that is produced by macrophages and T-cells is a potent inhibitor of macrophagederived inflammatory cytokines synthesis [54]. As pathogen activates the innate immune response through activation of the NF- $\kappa \mathrm{B}$ signaling pathways which is essential to the generations of inflammatory cytokines as TNF- $\alpha$ and interleukins which played a crucial role in fighting infection [55].In the current study, E.coli infected group showed a significant increase in serum level of TNF- $\alpha$ and IL-10. That may be also attributed to the essential role of TNF- $\alpha$ in the pathogenesis of liver damage caused by $E$. Coli derived endotoxin, subsequently increased IL-10 production as a direct protective effect against E.coli induced liver injury to suppress the host defense [56]. Furthermore, Xie et al. [57] reported a positive correlation with Gram -ve bacterial infection and increased IL-10 in serum, thus, IL-10 could serve as potential biomarkers for distinguishing Gram+ve infection from Gram -ve one.

Our data further suggested that treatment with CFPM improved the changes in the TNF- $\alpha$ and IL-10 levels induced by E.coli infection. This is in parallel with Arhoumah [58] who revealed that CFPM at dose $45 \mathrm{mg} / \mathrm{kg}$ bw significantly ameliorated the alterations in TNF- $\alpha$ and IL-10 levels induced by I/P injection with $E$. coli LPS which attributed to the immunomodulatory effect of CFPM.

\section{Conclusion}

Overall our results, using of broad-spectrum antibiotics as cefepime in a fixed-dose once daily for 5 consecutive days effective, safe and possess antioxidant, free radical scavenging potential and reduce inflammatory response that contribute in improving its efficacy against adverse effect induced by E.coli infection. Therefore, our results suggest that cefepime is a good choice for the treatment of E.coli infection, but still further studies are needed for evaluating the impact of higher doses of cefepime.

\section{Acknowledgment}

\section{Conflict of interest}

There is no conflict of interest in the current research work.

\section{Reasearch Ethics Committee Permission}

The study was approved by the Research Ethical Committee of the Faculty of Veterinary Medicine, Mansoura.University.

\section{Authors' contribution}

All authors contributed in planning the research, data analysis and manuscript writing and review of the final manuscript. Huda Elbaz was responsible for conducted the experimental study and all laboratory measurements. All authors approved the final version of the manuscript.

\section{REFERENCES}

[1] Alberti C, Brun-Buisson C, Burchardi H, Martin C, Goodman S, Artigas A, et al. Epidemiology of sepsis and infection in ICU patients from an international multicentre cohort study. Intensive Care Med 2002;28:108-21. https://doi.org/10.1007/s00134-0011143-z

[2] El-Boshy ME-S, Abdalla OA, Hassan A. Studies on the Immunomodulatory Effects of Lactoferrin in Rats Infected with E. coli. J Immune Based Ther Vaccines 2013;02:39-43.

https://doi.org/10.4236/jibtva.2013.24005 
[3] Ali IH, Jabir MS, Al-Shmgani HSA, Sulaiman GM, Sadoon $\mathrm{AH}$. Pathological and Immunological Study On Infection With Escherichia Coli In ale BALB/c mice. J Phy Conf Ser 2018;1003:012009. https://doi.org/10.1088/17426596/1003/1/012009

[4] Dutta P, Borah M, Sarmah R, Gangil R. Isolation, histopathology and antibiogram of Escherichia coli from pigeons Columba livia. Vet World 2013;6:91-4. https://doi.org/10.5455/vetworld.2013.91-94

[5] Huang S, Lee S, Lee N, See L, Tsai M, Shieh W. Comparison of in vitro activities of levofloxacin, ciprofloxacin, ceftazidime, cefepime, imipenem, and piperacillintazobactam against aerobic bacterial pathogens from patients with nosocomial infections. J Microbiol Immunol 2007;40:134.

[6] Muldoon EG, Epstein L, Logvinenko T, Murray S, Doron SI, Snydman DR. The impact of cefepime as first line therapy for neutropenic fever on Clostridium difficile rates among hematology and oncology patients. Anaerobe 2013;24:79-81.

https://doi.org/10.1016/j.anaerobe.2013.10.001

[7] Rhodes A, Evans LE, Alhazzani W, Levy MM, Antonelli M, Ferrer R, et al. Surviving sepsis campaign: international guidelines for management of sepsis and septic shock: 2016. Intensive Care Med 2017;43:304-77. https://doi.org/10.1007/s00134-017-4683-6

[8] Goethaert K, van Looveren M, Lammens C, Jansens $H$, Baraniak A, Gniadkowski M, et al. High-dose cefepime as an alternative treatment for infections caused by TEM24 ESBL-producing Enterobacter aerogenes in severely-ill patients. Clin Microbiol Infect 2006;12:56-62. https://doi.org/10.1111/j.1469-0691.2005.01290.x

[9] Chaudhary M, Soni A, Dwivedi VK. Fixed dose combination of cefepime plus amikacin prevent oxidative stress in liver of Mus musculus mice. Curr Clin Pharmacol 2008;3:211-4. https://doi.org/10.2174/157488408785747683

[10] Sánchez E, Such J, Teresa Chiva M, Soriano G, Llovet T, Mercè J, et al. Development of an Experimental Model of Induced Bacterial Peritonitis in Cirrhotic Rats with or without Ascites. AM J Gastroenterol 2007;102:1230-6. https://doi.org/10.1111/j.1572-0241.2007.01182.x

[11] Elsayed MG, Elkomy AA, Gaballah M, Elbadawy M. Nephrotoxicity of cefepime: A new cephalosporin antibiotic in rats. J Pharmacol Pharmacother 2014;5:33. https://doi.org/10.4103/0976-500X.124419

[12] Fernandez-Botran R, Gorantla V, Sun X, Ren X, PerezAbadia G, Crespo FA, et al. Targeting of glycosaminoglycan-cytokine interactions as a novel therapeutic approach in allotransplantation. Transplantation 2002;74:623-9. https://doi.org/10.1097/00007890-200209150-00007

[13] Feldman BF, Zinkl JG, Jain VC. Schalm's Veterinary Hematology, 5th ed. Canada: Lippincott Williams \& Wilkins; 2000.

[14] Akinbi HT, Epaud R, Bhatt H, Weaver TE. Bacterial Killing Is Enhanced by Expression of Lysozyme in the Lungs of
Transgenic Mice. J Immunol 2000;165:5760-6. https://doi.org/10.4049/jimmunol.165.10.5760

[15] Welker TL, Lim C, Yildirim-Aksoy M, Klesius PH. Growth, immune function, and disease and stress resistance of juvenile Nile tilapia (Oreochromis niloticus) fed graded levels of bovine lactoferrin. Aquaculture 2007;262:15662. https://doi.org/10.1016/j.aquaculture.2006.09.036

[16] Montgomery HAC, Dymock JF. Determination of nitric oxide. Analyst. 1961;86:41-3.

[17] Juhász K, Buzás K, Duda E. Importance of reverse signaling of the TNF superfamily in immune regulation. Expert Rev Clin Immunol 2013;9:335-48. https://doi.org/10.1586/eci.13.14

[18] Lobell A, Weissert R, Storch MK, Svanholm C, de Graaf KL, Lassmann $\mathrm{H}$, et al. Vaccination with DNA Encoding an Immunodominant Myelin Basic Protein Peptide Targeted to Fc of Immunoglobulin G Suppresses Experimental Autoimmune Encephalomyelitis. J Exp Med 1998;187:1543-8. https://doi.org/10.1084/jem.187.9.1543

[19] Bancroft JD, Stevens A, Turner DR. Theory and practice of histological techniques, 3rd ed. Edinburgh, London: Clurechill Livingston; 1990.

[20] Mohawk KL, O'Brien AD. Mouse models of Escherichia coli 0157: H7 infection and shiga toxin injection. Biomed Res Int 2011;2011:1-17. https://doi.org/10.1155/2011/258185

[21] Gupta K, Donnola SB, Sadeghi Z, Lu L, Erokwu BO, Kavran $M$, et al. Intrarenal Injection of Escherichia coli in a Rat Model of Pyelonephritis. J Vis Exp 2017:e54649. https://doi.org/10.3791/54649

[22] Gutierrez K. Pharmacology Review. Newer Antibiotics: Cefepime. 2004; 5:e382-e6. https://doi.org/10.1542/neo.5-9-e382

[23] Chudanova T, Abdulkadyrov K, Chebotkevich V. Cefepime/amikacin in the empirical antibacterial therapy for patients with hemoblastosis of different forms. Antibiot Khimioter 2003;48:29-32.

[24] Liang WJ, Wilson KJ, Xie H, Knol J, Suzuki S, Rutherford NG, et al. The gusBC Genes of Escherichia coli Encode a Glucuronide Transport System. J Bacteriol 2005;187:2377-85.

https://doi.org/10.1128/JB.187.7.2377-2385.2005

[25] Abou-Samra SA. Effects of Cefepime on Male Rats. Master Thesis Fac Vet Med Alex Univ ; 2012.

[26] Arhoumah AMM, Risha EF, Amer MSM, Abdalla OA. Efficacy of cefepime, tenoxicam and their combination on some hematological \& biochemical parameters against induced experimentally feverish rats. AVAS 2018;5.

[27] Ogundare AO, Onifade AK. The antimicrobial activity of Morinda lucida leaf extract on Escherichia coli. J Med Plant Res 2009;3:319-23.

[28] Contreras-Zentella ML, Hernández-Muñoz R. Is Liver Enzyme Release Really Associated with Cell Necrosis Induced by Oxidant Stress? Oxid Med Cell Longev 2016;2016:1-12.

https://doi.org/10.1155/2016/3529149 
[29] Chand N, Sanyal AJ. Sepsis-induced cholestasis. J Hepatol 2007;45:230-41. https://doi.org/10.1002/hep.21480

[30] deLemos AS, Friedman LS. Systemic Causes of Cholestasis. Clin Liver Dis 2013;17:301-17. https://doi.org/10.1016/j.cld.2012.11.001

[31] Unger LS, Cryer HM, Garrison RN. Differential response of the microvasculature in the liver during bacteremia. Circ Shock 1989;29:335-44.

[32] Nagano I, Kato S, Nimura Y, Wakabayashi T. Hepatic mitochondrial changes in experimental obstructive jaundice complicated by biliary infection. Hepatogastroenterol 1994;41:432-7.

[33] Prajapati B, Singha M. Comparative evaluation of the toxicity of Amikacin and Cefepime on rat's kidney and liver. Int J Pharmtech Res 2010;3:2149-54.

[34] Oter S, Edremitlioglu M, Korkmaz A, Coskun O, Kilic D, Kisa $U$, et al. Effects of hyperbaric oxygen treatment on liver functions, oxidative status and histology in septic rats. Intensive Care Med 2005;31:1262-8. https://doi.org/10.1007/s00134-005-2701-6

[35] Risha EF. Clinicopathological studies on the antibacterial effect of some medical plant in Guinea pig. PhD Thesis . Fac Vet Med, Mans Univ; 2010.

[36] Alamgir S, Volkova NB, Peterson MW. Prognostic Value of Low Blood Glucose at the Presentation of E.coli Bacteremia. Am J Med 2006;119:952-7. https://doi.org/10.1016/j.amjmed.2006.03.035

[37] Dembovska K, Svoboda P, Scheer P, Kantorova I, Tomenendalova J, Rehakova K, et al. Model of septic shock induced by live E. coli (O18) in a laboratory rat. Vet Med 2008;53:153-64. https://doi.org/10.17221/1942VETMED

[38] Bradley JS, Sauberan JB. Antimicrobial Agents. In: Long SS, Pickering LK, Prober CG, editors. Principles and practice of pediatric infectious disease, 4th ed. New York, USA: J Res Health Sci 2012. p. 1453-84.

[39] Li J, Wang X, Ackerman W, Batty A, Kirk S, White W, et al. Dysregulation of Lipid Metabolism in Mkp-1 Deficient Mice during Gram-Negative Sepsis. Int J Mol Sci 2018;19:3904. https://doi.org/10.3390/ijms19123904

[40] Ozbudak O, Ozbudak IH, Turkay C, Sahin N, Ozdem S, Turkay $\mathrm{M}$, et al. Effect of a cholesterol rich diet, recurrent infection and possible treatment modalities on the pulmonary vascular system: an experimental study. W Indian Med J 2011;60:132-6.

[41] Mandal A, Patra A, Mandal S, Roy S, Mahapatra SD, Mahapatra TD, et al. Therapeutic potential of different commercially available synbiotic on acetaminopheninduced uremic rats. Clin Exp Nephrol 2015;19:168-77. https://doi.org/10.1007/s10157-014-0971-4

[42] Inci M, Davarci M, Inci M, Motor S, Yalcinkaya FR, Nacar $E$, et al. Anti-inflammatory and antioxidant activity of thymoquinone in a rat model of acute bacterial prostatitis. Hum Exp Toxicol 2013;32:354-61. https://doi.org/10.1177/0960327112455068

[43] Kilany OE, Youssef F, Mabrouk M, Fares IM. Clinicopathological Studies on the Effect of Some
Antibacterial Medicinal Plants in Broilers. J Clin Pathol Forecast 2018;1:1003.

[44] Soejima A, Ishizuka S, Miyake N, Fukuoka K, Suzuki M, Kamiya $Y$, et al. Simultaneous inhibition of renal phospholipase A2 and glutathione synthesis by manoalide and DL-buthionine sulfoximine induces acute tubular dysfunction in rats. Nephron Exp Nephrol 2000;8:84-90. https://doi.org/10.1159/000020653

[45] Maraghi S, Molyneux DH, Wallbanks KR. Lysozyme activity in the plasma of rodents infected with their homologous trypanosomes. Iran J Parasitol 2012;7:86.

[46] Yersin B, Glauser MP, Guze PA, Guze LB, Freedman LR. Experimental Escherichia coli endocarditis in rats: roles of serum bactericidal activity and duration of catheter placement. Infect Immun 1988;56:1273-80. https://doi.org/10.1128/IAI.56.5.1273-1280.1988

[47] Paulsen SM, Lunde H, Engstad RE, Robertsen B. In vivo effects of $\beta$-glucan and LPS on regulation of lysozyme activity and mRNA expression in Atlantic salmon (Salmo salar L.). Fish Shellfish Immun 2003;14:39-54. https://doi.org/10.1006/fsim.2002.0416

[48] Lowry VK, Farnell MB, Ferro PJ, Swaggerty CL, Bahl A, Kogut $\mathrm{MH}$. Purified $\beta$-glucan as an abiotic feed additive up-regulates the innate immune response in immature chickens against Salmonella enterica serovar Enteritidis. Int J Food Microbiol 2005;98:309-18. https://doi.org/10.1016/j.ijfoodmicro.2004.06.008

[49] Dey S, Bishayi B. Killing of Staphylococcus aureus in murine macrophages by chloroquine used alone and in combination with ciprofloxacin or azithromycin. J Inflamm 2015;8:29. https://doi.org/10.2147/JIR.S76045

[50] Thippeswamy T, McKay JS, Quinn JP, Morris R. Nitric oxide, a biological double-faced janus-Is this good or bad? Histol Histopathol 2006;21:445-58.

[51] Macdonald J, Galley HF, Webster NR. Oxidative stress and gene expression in sepsis. Brit J Anaesth 2003;90:221-32. https://doi.org/10.1093/bja/aeg034

[52] Zhao YL, Cen XB, Ito M, Yokoyama K, Takagi K, Kitaichi K, et al. Shiga-Like Toxin II Derived from Escherichia coli 0157:H7 Modifies Renal Handling of Levofloxacin in Rats. Antimicrob Agents Chemother 2002;46:1522-8. https://doi.org/10.1128/AAC.46.5.1522-1528.2002

[53] Coleman JW. Nitric oxide in immunity and inflammation. Int Immunopharmacol 2001;1:1397-406. https://doi.org/10.1016/S1567-5769(01)00086-8

[54] Chaudhry H, Zhou J, Zhong YIN, Ali MM, McGuire F, Nagarkatti PS, et al. Role of cytokines as a double-edged sword in sepsis. In Vivo 2013;27:669-84.

[55] Joseph B, Shimojo G, Li Z, Thompson-Bonilla MdR, Shah $R$, Kanashiro A, et al. Glucose Activates Vagal Control of Hyperglycemia and Inflammation in Fasted Mice. Sci Rep 2019;9:1-11. https://doi.org/10.1038/s41598-01836298-z

[56] Takano M, Nishimura H, Kimura Y, Washizu J, Mokuno Y, Nimura $Y$, et al. Prostaglandin E2 protects against liver injury after Escherichia coli infection but hampers the 
resolution of the infection in mice. J Immunol 1998;161:3019-25.

[57] Xie YJ, Duan JY, Zhang HR, Wang N, Liu Y-f, Wu X-I, et al. Establishment of the ICR mouse models of bloodstream infections induced by clinical strains. Chin J Nosocomiol 2014;24:521-3.
[58] Arhoumah AM. Clinicopathological studies on feverish rats treatedwith antibiotic and anti-Inflammatory. PhD Thesis . Fac Vet Med Mans Univ ; 2018. 